\title{
Individual variation in migratory movements and winter behaviour of Iberian Lesser Kestrels Falco naumanni revealed by geolocators
}

\author{
INÊS CATRY, ${ }^{1 *}$ MARIA P. DIAS, ${ }^{2,3}$ TERESA CATRY, ${ }^{4}$ VSEVOLOD AFANASYEV,${ }^{5}$ JAMES FOX,${ }^{5}$ \\ ALDINA M.A. FRANCO ${ }^{6} \&$ WILLIAM J. SUTHERLAND ${ }^{1}$ \\ ${ }^{1}$ Conservation Science Group, Department of Zoology, University of Cambridge, Downing Street, Cambridge CB2 3EJ, UK \\ ${ }^{2}$ Eco-Ethology Research Unit (ISPA), Rua Jardim do Tabaco 34, 1149-041 Lisbon, Portugal \\ ${ }^{3}$ Museu Nacional de História Natural, Rua da Escola Politécnica 56/58, 1250-102 Lisbon, Portugal \\ ${ }^{4}$ Centro de Estudos do Ambiente e do Mar (CESAM)/Museu Nacional de História Natural, Universidade de \\ Lisboa, Rua da Escola Politécnica 58, 1250-102 Lisbon, Portugal \\ ${ }^{5}$ British Antarctic Survey, Natural Environmental Research Council, High Cross, Madingley Road, \\ Cambridge CB3 OET, UK \\ ${ }^{6}$ School of Environmental Sciences, University of East Anglia, Norwich NR4 7TJ, UK
}

The population decline of the Lesser Kestrel Falco naumanni has been the subject of studies across its Western Palaearctic breeding range, but little is known about its use of pre-migratory areas or African wintering quarters. We used geolocators to describe the temporal and spatial patterns of Portuguese Lesser Kestrel migration and wintering behaviour. Data on the complete migration were obtained from four individuals and another three provided further information. Prior to southward migration, Lesser Kestrels showed two different behaviours: northward-orientated movements to Spain and movements in the proximity of the breeding area. Autumn migration took place mostly in late September; spring departures occurred mainly in the first half of February. Wintering grounds included Senegal, Mauritania and Mali, with individuals overlapping considerably in Senegal. Movements registered within the wintering grounds suggest itinerant behaviour in relation to local flushes of prey. During spring migration, birds crossed the Sahara Desert through Mauritania, Western Sahara and Morocco before passing over the Mediterranean to reach Portugal. Autumn migration lasted $4.8 \pm 1.1$ days, and spring migration lasted $4.1 \pm 0.3$ days. The mean daily flight range varied between approximately 300 and $850 \mathrm{~km}$ for an entire journey of around $2500 \mathrm{~km}$. Effective protection of roosting sites in both pre-migratory and wintering areas and maintaining grasshopper populations in Sahelian wintering quarters appear crucial in preserving this threatened migratory raptor across its African-Eurasian flyway. There was no evidence of any deleterious effects of fitting birds with loggers.

Keywords: geolocators, migration, pre-migratory movements, wintering range.

There is increasing conservation concern about migratory birds, many of which are classified as threatened or near-threatened. Half the migratory raptor species of the African-Eurasian flyway are globally threatened, near-threatened or declining

*Corresponding author.

Email: inescatry@yahoo.com
(BirdLife International 2009). Limited knowledge of their ecology outside the breeding grounds restricts assessment of threats and solutions (Biber \& Salathé 1990, Kelsey 1992). Determining the migratory schedule, route taken, stopover sites and wintering grounds is fundamental for effective conservation.

Current knowledge of avian migration patterns is largely derived from bird counts, radar observations 
and ring recovery analyses (Akesson \& Hedenström 2004, Newton 2008). Satellite telemetry has revolutionized the study of bird migration (e.g. Weimerskirch et al. 2006, Strandberg et al. 2008, Qian et al. 2009), but inherent limitations, such as instrument size and mass, high device costs and significant tag loss (Phillips et al. 2004) mean that satellite tracking studies are only applied to large and medium-sized species and typically involve a small sample size (e.g. Ganusevich et al. 2004, Meyburg et al. 2004, 2005).

Miniature light-level loggers (geolocators; also known as global location sensing) have recently been developed for long-distance tracking of marine birds and mammals (Afanasyev 2004, Phillips et al. 2004). Their small size, low cost, long battery life and ease of attachment (for example to a leg ring) have increased the range of species whose movements can be followed remotely (Phillips et al. 2006, Rayner 2007, Catry et al. 2009a) and increased the opportunity to study individual differences (González-Solís et al. 2007). This technology has largely been used in seabird studies (but see Eichhorn et al. 2006, Stutchbury et al. 2009, Rodríguez et al. 2009).

In this study, we used geolocators to track the migratory schedule of the Lesser Kestrel Falco naumanni, a migratory falcon classified as globally Vulnerable (BirdLife International 2004) whose breeding range extends from the Mediterranean across southern central Asia to China and Mongolia (BirdLife International 2004). The non-breeding range is in Africa, although a few adults overwinter in Spain and southern Turkey (Cade 1982, Negro et al. 1991). Eastern populations, comprising those in eastern Europe, Middle East and Asia, winter mainly in eastern Africa and South Africa (Pepler \& Martin 2001). Data on the numbers and distribution of western Lesser Kestrels outside the breeding range are scarce (Pilard et al. 2004). However, in 2007, a single roost of over 28600 Lesser Kestrels was discovered in Senegal (LPO 2008), which may have contained $30-50 \%$ of the entire western European population, probably including birds from Portugal, Spain, France and Morocco (Pilard 2008), while Rodríguez et al. (2009) described the wintering ranges of three Spanish birds in West Africa, based on geolocation data. Despite this, there is no knowledge of migratory routes and little information is available on the distribution and movements of Lesser Kestrels in their wintering grounds.
The Lesser Kestrel is one of the most gregarious of the Falco species during breeding, wintering and prior to autumn migration (Olea et al. 2004, Minias et al. 2009). Pre-migratory movements are thought to exploit temporarily superabundant food resources to improve body condition before migration (Olea 2001, Ursúa \& Tella 2001). These areas have been suggested to be regular pre-migratory areas with ecological and conservation importance for Lesser Kestrel populations (Olea et al. 2004). However, little is published on pre-migratory movements, with all studies focusing on juvenile dispersal, based on ring recoveries (Bustamante \& Negro 1994, Olea 2001).

The aim of this study was to describe the complete annual migratory track and schedule of adult Lesser Kestrels breeding in Portugal. We analyse the temporal and spatial patterns of Lesser Kestrel migration, including pre-migratory movements, arrival and departure dates, routes taken, location of wintering areas and movements on wintering grounds, using recently developed geolocation techniques. Although increasing conservation efforts in the European breeding grounds of the Lesser Kestrel have proved effective (Pomarol 1996, Catry et al. 2009b), these efforts may be compromised if there are negative impacts in the pre-migratory areas and African wintering quarters. Information on the species' migration and winter ecology is necessary to identify threat priorities for conservation outside the breeding areas.

\section{METHODS}

\section{Logger deployment}

Nineteen Mk14 geolocators, built by the British Antarctic Survey (Afanasyev 2004), were attached to eight male and 11 female adult Lesser Kestrels from 28 March to 7 April 2008 in three different colonies at the Castro Verde Special Protection Area, southern Portugal. This area harbours almost 80\% (about 430 breeding pairs) of the Portuguese Lesser Kestrel population and the colonies are mainly located in old rural buildings and artificial nesting structures (Catry et al. 2009b). Each 1.5-g geolocator was attached with a single cable tie to a PVC colour ring (total weight $2.3 \mathrm{~g}$ ) and placed around the bird's tarsus. Tracked individuals weighed 127-188 g, thus the attachment represented less than $2 \%$ of the body mass. All individuals were captured in nest-cavities at night prior to 
egg-laying. Lesser Kestrels are highly philopatric but move between nests within colonies (Serrano et al. 2001). To increase the recapture probability, we selected colonies with high recapture rates. A high proportion of these populations were marked, enabling selection of birds with a known breeding history. The loggers were attached to birds aged 1-5 years at deployment; 11 were recovered in the next breeding season. For calibration, a daylight logger was placed during the entire study period close to the colonies.

\section{Analysis of light data}

Light data from retrieved loggers were analysed using TRANSEDIT software (British Antarctic Survey 2008) to check the integrity on light curves and to fit sunset and sunrise times (10 was used as the light threshold value). Longitude, derived from the absolute time of local noon/midnight relative to Greenwich Mean Time, and latitude, derived from day length, was estimated using BIRDTRACK software (British Antarctic Survey 2008), providing two locations per day. Using known positions obtained from the deployed and calibration loggers during the breeding and winter periods, respectively, the sun elevation angle was set to $-4.0^{\circ}$. Locations derived from curves with obvious shading events around sunset and sunrise were identified and excluded. In addition, we discarded locations obtained around the equinoxes ( \pm 21 days), when day and night length are similar, so preventing the estimation of latitude (Wilson et al. 1992, Hill 1994). Mean accuracy was first assessed from variation during the breeding season, when birds remain close to the colony, allowing assessment of the influence of their behaviour. Mean accuracy was estimated to be $224 \pm 15 \mathrm{~km}$ ( $n=128$ positions). From the calibration logger during the winter period (16 October-31 January) error was calculated as $283 \pm 13 \mathrm{~km}$ ( $n=152$ positions). In both cases, longitude is more accurate than latitude, particularly during the winter period (longitude $127 \pm 7 \mathrm{~km}$ vs. latitude $171 \pm 16 \mathrm{~km}$ during the breeding period, and $60 \pm 4 \mathrm{~km}$ vs. $273 \pm 13 \mathrm{~km}$ during winter).

\section{Statistical procedures}

The main pre-migratory and wintering areas were identified by determining each individual's kernel distribution. These maps were based on the projected (UTM 28N) and twice-smoothed positions (i.e. by calculating, for each position, its average with the positions immediately after and before, and repeating this procedure twice; Phillips et al. 2004). Lesser Kestrel autumn migration (and part of spring migration for some birds) coincides with the equinoxes, which prevent the determination of the precise routes. Therefore, we estimated the departure and arrival dates associated with migration movements from longitude data (Rodríguez et al. 2009, Stutchbury et al. 2009). We identified the beginning of each migratory journey by the clear shift in longitude values, followed by a unidirectional and sharp variation in longitude (of approximately two degrees of longitude per day). Similarly, arrival dates were considered as the day at which longitude values stabilized. The correlation between days and longitude values was always high and significant during migration ( $|r|$ always higher than 0.87; $P$ always lower than 0.01 ), contrasting with the much lower correlation values during the days immediately before and after migration ( $|r|$ always lower than 0.5). Distances between wintering and breeding areas were computed with unprojected but smoothed data (greatcircle distances), assuming the mean position during the winter period. Given the low accuracy of the estimated locations, we used a conservative approach when calculating migratory distances and speeds by assuming an error of $273 \mathrm{~km}$ in latitude and $60 \mathrm{~km}$ in longitude values (see above) and by presenting minimum and maximum estimates for these parameters. All analyses were performed using software R 2.6.1 (R Development Core Team 2007), and the relevant packages PROJ4 (Urbanek 2007) and ADEHABITAT (Calenge 2006). Final maps were produced using ARCVIEW 3.2 (ESRI 1999). All means are given with standard errors.

\section{RESULTS}

\section{Logger retrieval and device effects}

Of the initial 19 loggers deployed in 2008, 11 were retrieved during 2009. From these, three had entered a 'sleep mode' at different stages after deployment and stopped recording data prior to spring migration. Nonetheless, for one female (6776) it was possible to obtain information on its pre-migratory behaviour. From the remaining seven, four had onboard clock errors (i.e. large clock drifts, resulting in large errors in locations 
registered during the first months of tracking); however, for three of the four, it was possible to collect data related to migratory schedules, which were based solely on clear shifts in longitude data (Table 1). Device problems among retrieved loggers were largely due to physical damage caused by the birds themselves, a problem that has been reported for some terrestrial species, including Lesser Kestrels (Rodríguez et al. 2009). Finally, four loggers (all deployed on females) provided data for the entire migration and wintering period $(71 \%$ of valid locations on average; minimum 58\%; maximum $78 \%$ ), allowing the analysis of main migratory movements and wintering areas (Table 1). There was no significant difference in mean body mass between birds with and without loggers when recaptured before the start of the incubation period $(163 \pm 19.3 \mathrm{~g}, n=9$ and $154 \pm 15.0 \mathrm{~g}, n=106$, respectively, $\quad t_{113}=-1.56, \quad P=0.121$ ). After deployment, two females in 2008 and two in 2009 were recaptured during colony monitoring: all successfully produced fledglings $(n=5,4,3$ and 1$)$. One female with a logger was the first to lay and had the largest clutch (six eggs) of any within the colony.

\section{Pre-migratory movements from the breeding area}

Two Lesser Kestrels made northward movements from their breeding area prior to autumn migration. One female (6773) moved over $700 \mathrm{~km}$ from 19 July to northeast Spain, while the other (6776) left the breeding area in the first days of August, moving north to Spain (Fig. 1). Two other birds made shorter movements but because of insufficient accuracy of achieved locations we could not determine whether the tracked individuals stayed in Portugal or moved to areas near the border (perhaps to the largest known pre-migratory roosting site in the Spanish Extremadura, less than $150 \mathrm{~km}$ northeast of Castro Verde).

\section{Autumn migration}

Autumn migration started in September, with most birds departing in the second half of the month (mean $=23$ September \pm 3.34 days), and lasted $4.8 \pm 1.1$ days $(n=4$, Table 1$)$. The average speed was approximately $600 \mathrm{~km} /$ day, covering a mean distance of $2500 \mathrm{~km}$ between breeding and wintering grounds (Table 1). Tracked Lesser
Kestrels reached the wintering areas from 17 September to 2 October (mean $=26$ September \pm 3.35 days, $n=4$, Table 1 ). It was impossible to identify the route taken because the large errors in latitude during the equinox obliged us to discard location data from this period (see Methods).

\section{Wintering period}

Data from eight of 11 retrieved geolocators indicate that all eight birds did migrate (three devices entered sleep mode prior to migration) and probably wintered in western Africa, spending part of the winter period in Senegal (Table 1). The wintering period for the four tracked birds with usable data for the entire period lasted for $136 \pm 3.32$ days (Table 1). Two birds spent part of the winter in Mauritania (and one might have moved to Mali) but individual core areas of activity $(25,50,75$ and 95\% kernels) overlapped considerably in Senegal (Fig. 2). Minimum and maximum latitudes of wintering areas (95\% kernels) ranged between $10.6^{\circ} \mathrm{N}$ and $18.7^{\circ} \mathrm{N}$, where the habitat is dominated mainly by tropical grasslands, savannas and shrublands. Gradual movements to both the west and east were detected during the wintering period, as shown by the variation in longitude values (Fig. 3). Female 6773 migrated to the border of Mauritania and Mali, where it stayed until 25 October, then moving to Senegal for a month (from 26 October to 21 November), and returned to the Mauritania/Mali area until spring migration (Figs 2 and 3). The limits of its core areas were more than $800 \mathrm{~km}$ apart. Two other birds (6772 and 6774) showed relatively large areas of movement, whereas female 6781 apparently stayed in the same area from November until the beginning of spring migration (Fig. 3).

\section{Spring migration}

Spring departure from the wintering grounds occurred from 9 February to 9 March (mean $=15$ February \pm 3.94 days, $n=7$; Table 1). All individuals crossed the Sahara Desert through Mauritania, Western Sahara and Morocco before passing over the Mediterranean to reach the Portuguese breeding grounds (Fig. 2). Female 6773 took a slightly different route and may have crossed the Strait of Gibraltar (Fig. 2). On average, spring migration took $4.1 \pm 0.3$ days $(n=7)$ with distance travelled averaging $650 \mathrm{~km} /$ day $(n=4$, Table 1). Arrival 


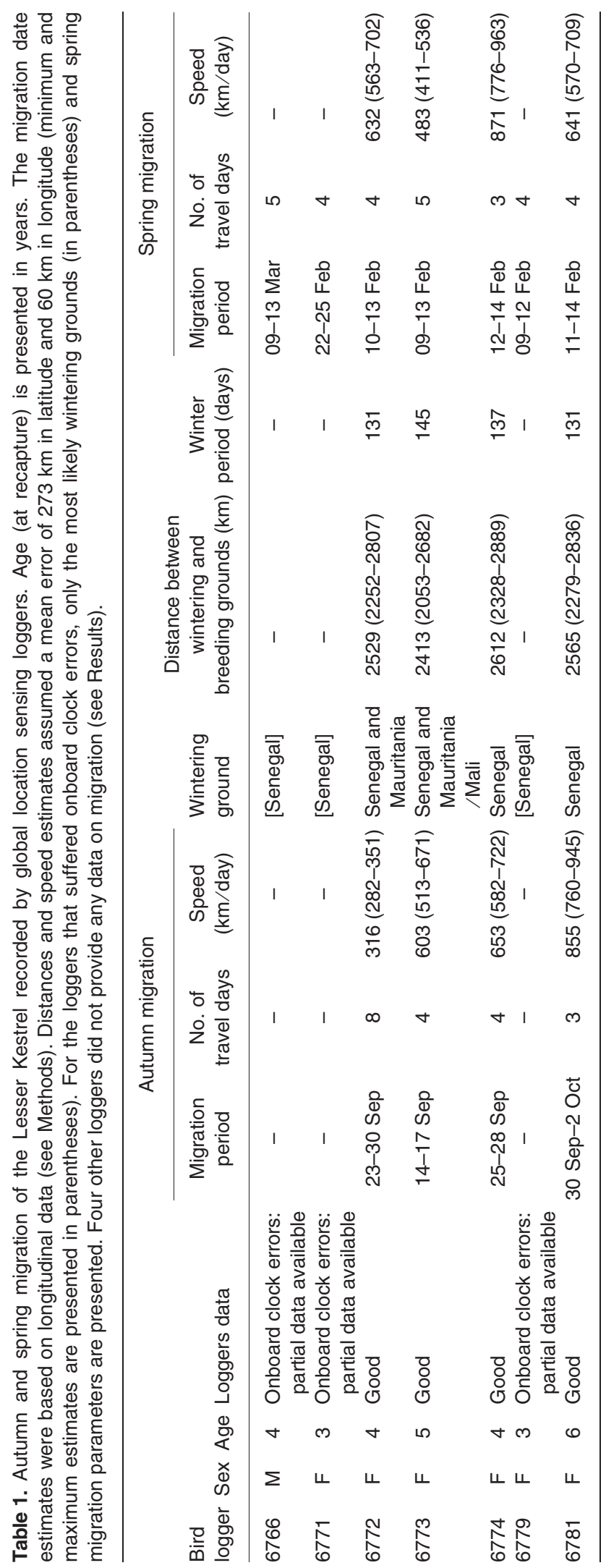




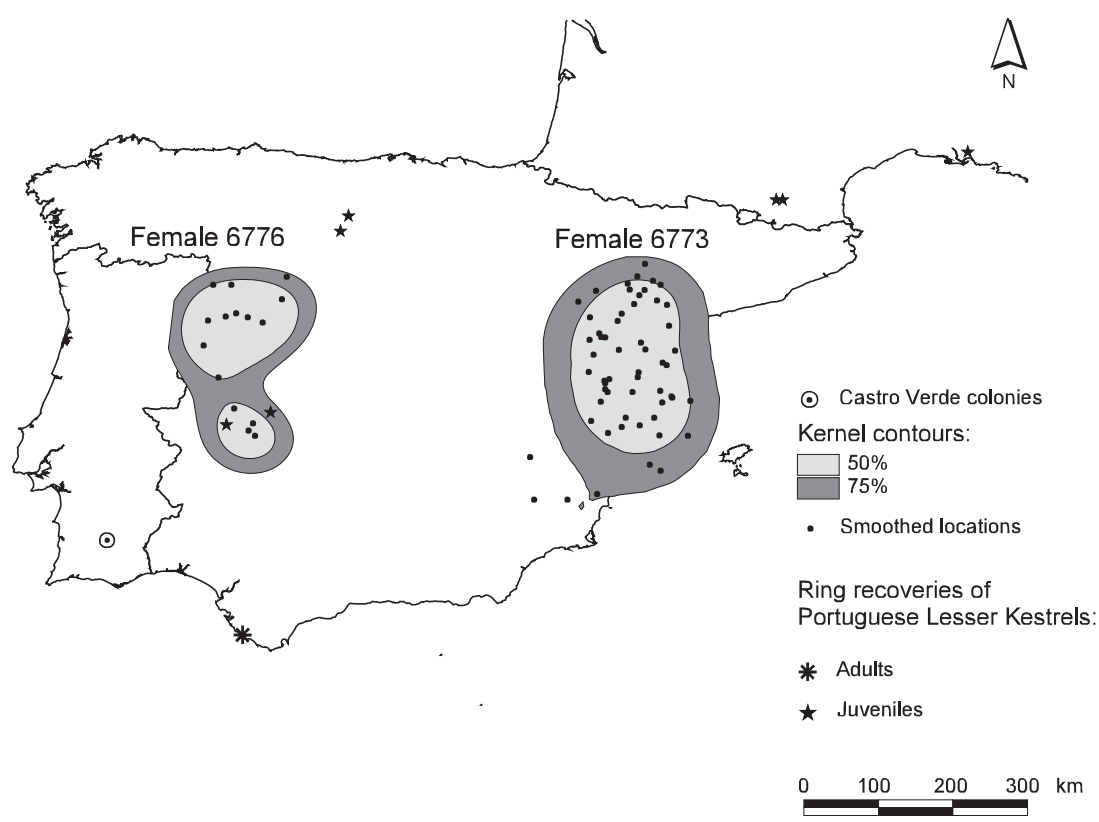

Figure 1. Pre-migratory movements and kernel activity ranges (encompassing 50 and $75 \%$ of the locations) of two Lesser Kestrel females prior to autumn migration. Recovery sites of ringed Portuguese Lesser Kestrels (and recovered elsewhere in July, August and September of the same year) are shown.

dates at the breeding grounds were from 12 February to 13 March (mean $=18$ February \pm 4.06 days, $n=7$; Table 1). Female 6773 arrived on 13 February and laid the first egg more than 2 months later, on 21 April.

\section{DISCUSSION}

\section{Logger retrieval, device effects and data quality}

Eleven of 19 tagged birds (58\%) were recaptured and the geolocators retrieved. Relatively high return rates, non-significant differences in individual body condition among birds with and without devices and successful breeding for the few monitored tagged birds suggest minimal impact of logger deployment, as also shown by Rodríguez et al. (2009). Mean geolocator accuracy $(224 \pm 15$ and $282 \pm 13 \mathrm{~km}$ during the breeding and wintering periods, respectively) was lower than seabird tracking results (e.g. $186 \pm 114 \mathrm{~km}$, Phillips et al. 2004; $202 \pm 171 \mathrm{~km}$, Shaffer et al. 2005) due to high light interference in terrestrial habitats (from shadowing effects, for example). However, our conclusions are mainly based on large-scale movement patterns, typically based solely on longitude data (as the within-winter or the spring migratory movements), resulting in reduced errors. We therefore believe that the magnitude of the geolocation error does not alter any of our main findings.

\section{Pre-migratory movements from the breeding area}

Ring recoveries show juvenile northward movements prior to southward migration (Fig. 1; Bustamante \& Negro 1994, Olea 2001), probably to areas where orthopteran abundance peaks later, thus enhancing juvenile survival and improving body condition before migration (Olea 2001, Ursúa \& Tella 2001). Nevertheless, adult premigratory movements have rarely been recorded (Fig. 1; Riols \& Pilard 2007) and previous studies suggest that they disperse less than juveniles or remain near their breeding colonies until migration (Bustamante \& Negro 1994, Olea et al. 2004). We observed two different behaviours in our tracked adult individuals: two birds clearly made premigratory movements, possibly gathering in known post-nuptial roosts in northwestern and northeastern Spanish provinces of Léon, Arágon and Navarra (Ursúa \& Tella 2001, Olea et al. 2004), whereas another two made local movements. 

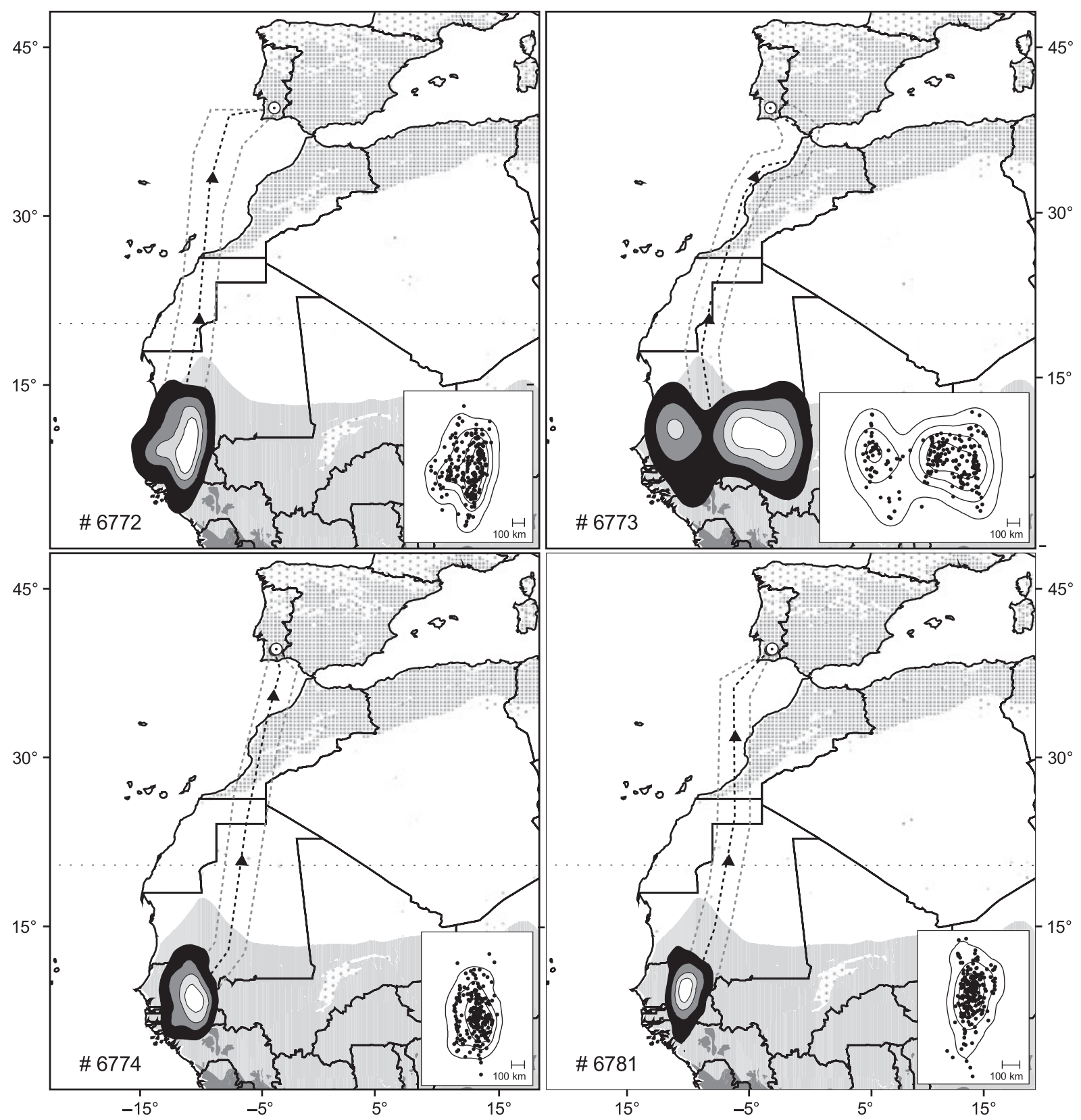

Kernels contour

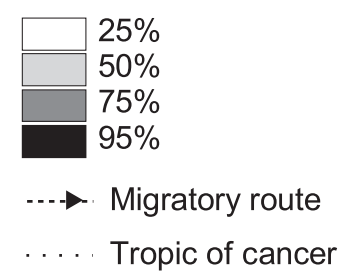

\section{Habitats}

Deserts and xeric shrublands

Mediterranean scrub

Tropical and subtropical grasslands, savannas, and shrublands

Tropical and subtropical moist broadleaf forests

Other

$\odot$ Castro Verde colony

Figure 2. Individual core areas (25, 50, 75 and $95 \%$ kernel contours) of Lesser Kestrel activity during the wintering period (21 October to 31 January) and spring migratory routes to breeding areas in Castro Verde, Portugal. Grey dashed lines along the migratory trajectory represent the confidence intervals assuming a 124-km error in longitudes (see Methods). Locations in which the kernels were based are plotted in the lower part of each panel. 

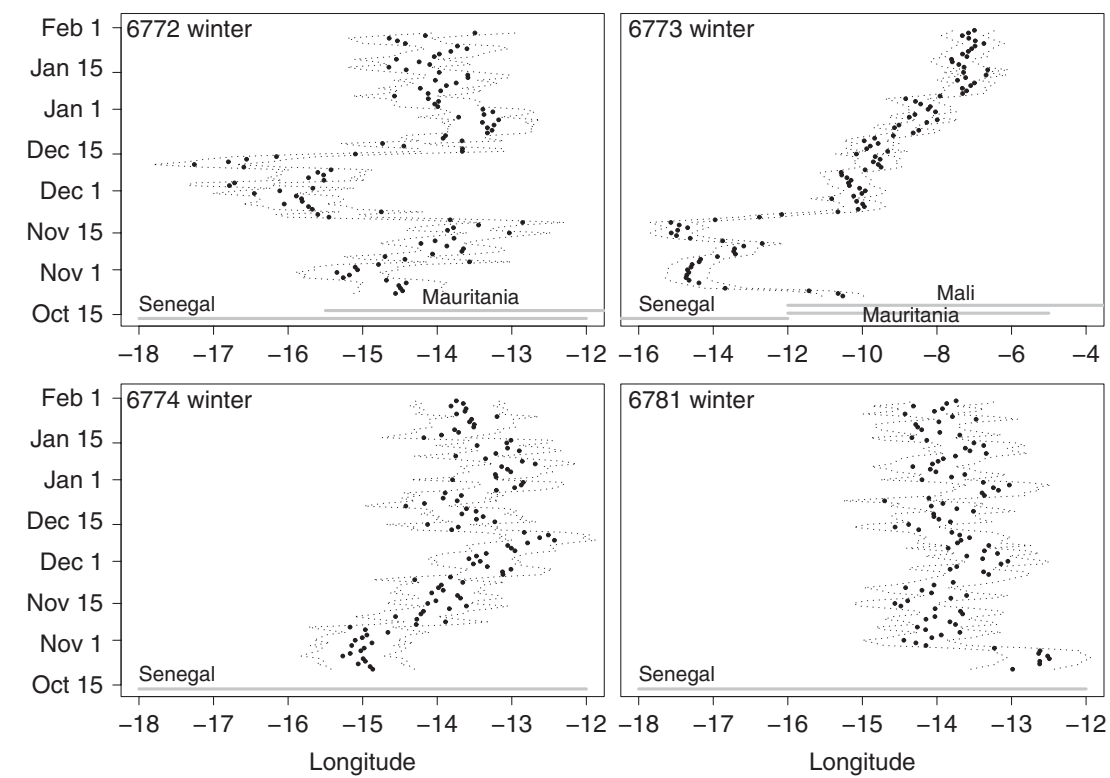

Figure 3. Winter behaviour of tracked Lesser Kestrels in western Africa. Longitude variation reveals different patterns of movement among four females. Each point corresponds to the average longitude of the date (two locations per day). Dashed lines represent the estimated error for the longitude (60 km, or $0.56^{\circ}$, see Methods), assuming a mean latitude of $15^{\circ} \mathrm{N}$.

\section{Autumn and spring migration: timing, routes, duration, distance and speed}

Our data, based on seven tracked individuals, agree with the timing of autumn migration observed across the Strait of Gibraltar (late September; Róman et al. 2008), whereas spring passage took place earlier than suggested (late February and early March; Róman et al. 2008), with five of seven of the birds crossing the Mediterranean before 15 February. Southward and northward migratory journeys were of similar durations $(4.8 \pm 1.1$ and $4.1 \pm 0.3$ days, respectively) Although the timing and duration of post-nuptial migration were similar to the results from Rodriguez et al. (2009) in southern Spain, spring migration and arrival at the breeding grounds differed markedly $(24.3 \pm 10$ days, with arrivals in late March, $n=3$ ). The shorter duration of spring migration found in our study is supported by the unmistakable pattern of light transition values across the day (dark and light) when birds started to visit the breeding cavities. The mean daily flight distance during migration ranged for different individuals between approximately 300 and $850 \mathrm{~km}$, covering a distance of about $2500 \mathrm{~km}$. Medium and large raptors tracked by satellite techniques only occasionally move more than $500 \mathrm{~km} /$ day
(Newton 2008). Nonetheless, among the Falco genus, recent data recorded from a Hobby Falco subbuteo revealed a non-stop flight over a distance of $740 \mathrm{~km}$ in $25 \mathrm{~h}$ (Strandberg et al. 2009). Observed spring migratory routes (only one bird might have crossed the Mediterranean through Gibraltar) reinforce the idea that Lesser Kestrels are capable of crossing the Mediterranean over broad fronts (Greenberg \& Marra 2005).

\section{Wintering range}

After crossing the Sahara Desert, all individuals, and those of Rodríguez et al. (2009), spent at least part of the winter period in Senegal. Overall, Portuguese Lesser Kestrels wintered further east than Spanish ones (Rodríguez et al. 2009), with some birds apparently not using the area adjacent to the recently discovered large roost (28 000 individuals; LPO 2008) in western Senegal. They may have been using the smaller and less stable peripheral roosts recently discovered over $100 \mathrm{~km}$ further east (P. Pilard, pers. comm.). As for all migrant species (Sherry \& Holmes 1996), food is probably the most important ecological factor affecting distribution and movements of Lesser Kestrels across their winter quarters. Grasshopper abundance and distribution in the Sahelian area are 
driven mainly by the annual movement of the InterTropical Convergence Zone, which determines the rainfall patterns and the distribution of habitats (Jones 1995). In Senegal, recent land cover changes have led to changes in the distribution pattern of grasshoppers (Mullié 2009) and might explain the present location of core areas of activity for Lesser Kestrels. Surveys showed that the newly created steppes and grasslands attracted very high numbers of acridivores, including Lesser Kestrels, dispersed over a feeding area of c. $3500 \mathrm{~km}^{2}$ (Mullié 2009). The movements observed during the wintering period (within Senegal and to Mali and Mauritania) suggest some itinerancy in relation to local flushes of food, and this is considered to be the main strategy among raptor species wintering in Africa (Newton 2008). High concentrations of several raptor species (including Lesser Kestrels) in large communal roosts close to Desert Locust Schistocerca gregaria swarms during the outbreak of 2004 have been detected in Mauritania (Sánchez-Zapata et al. 2007). Among Lesser Kestrels, displacements of more than $200 \mathrm{~km}$ from usual roosts were identified in South Africa in response to increasing food densities (Pepler \& Martin 2001).

\section{Conservation implications}

Declines of raptors in West Africa have been attributed to deforestation, agricultural intensification, overgrazing, erosion, pesticide use and illegal hunting (Thiollay 2006). It has been suggested that recent changes in land cover have resulted in increased grasshopper populations in vast Sahelian areas, so resulting in increased use of chemical insecticides (Mullié 2009). The implementation of tested biopesticides, less toxic for predator species, may be a viable alternative to the currently used broad-spectrum chemical products (LPO 2008, Mullié 2009).

The apparent fidelity of Lesser Kestrels to large roosts (Olea et al. 2004, LPO 2008) makes identifying and protecting these roosting sites important. Identified problems include agricultural intensification for pre-migratory sites (DEMA 2005) and human disturbance and woodcutting on the wintering grounds (LPO 2008, 2009).

This study presents new data on the migratory and wintering behaviour of Iberian Lesser Kestrels, which might be crucial for the conservation of this globally threatened species. Nonetheless, the limited number of successful tracked individuals underlines the need for further work to support the described patterns and increase the current knowledge of this species' migration.

We thank the CEMPA Ringing Bird Centre and Vitor Encarnação for providing information on Lesser Kestrel ring recoveries. We are grateful to Rui Constantino, Carla Veríssimo, Miguel Lecoq, Ruben Heleno, Mariza Gomes, Beatriz Estanque and the League for the Protection of Nature (LPN) for helping in the fieldwork. We thank R. Strandberg and one anonymous referee for useful comments on the manuscript. I.C., T.C. and M.P.D. were funded by Portuguese doctoral and post-doctoral grants from Fundação para a Ciência e Tecnologia (SFRH/BD/28023/ 2006, SFRH/BPD/46967/2008 and SFRH/BPD/46827/2008, respectively). W.J.S. was funded by the Arcadia Fund. This research was conducted with the permission of the ICNB, Portugal.

\section{REFERENCES}

Afanasyev, V. 2004. A miniature daylight level and activity data recorder for tracking animals over long periods. Mem. Natl Inst. Polar Res., Spec. Issue, 58: 227-233.

Akesson, S. \& Hedenström, A. 2004. Migration. In Sutherland, W.J., Newton, I. \& Green, R.E. (eds) Bird Ecology and Conservation: A Handbook of Techniques: 161-178. Oxford: Oxford University Press.

Biber, J.P. \& Salathé, T. 1990. Conservation Priorities for Migratory Birds of the European Community. Cambridge: International Council for Bird Preservation.

BirdLife International 2004. Birds in Europe: Population Estimates, Trends and Conservation Status. Cambridge: BirdLife International.

BirdLife International 2009. Born to Travel Campaign. Available at: http://www.borntotravelcampaign.com [accessed 13 October 2009].

British Antarctic Survey 2008. Migrating bird tracking logger. In BAS Research: Instruments and Techniques. Cambridge: British Antarctic Survey. Available at: http://www.antarctica.ac.uk [accessed 19 December 2009].

Bustamante, J. \& Negro, J.J. 1994. The post-fledging dependence period of the Lesser Kestrel (Falco naumanni) in southwestern Spain. J. Raptor Res. 28: 158-163.

Cade, T.J. 1982. The Falcons of the World. London: Cornell University Press.

Calenge, C. 2006. The package adehabitat for the R software: a tool for the analysis of space and habitat use by animals. Ecol. Model. 197: 516-519.

Catry, T., Ramos, J.A., Le Corre, M. \& Phillips, R. 2009a. Movements, at-sea distribution and behaviour of a tropical pelagic seabird: the wedge-tailed shearwater in the western Indian Ocean. Mar. Ecol. Prog. Ser. 391: 231242.

Catry, I., Alcazar, R., Franco, A.M.A. \& Sutherland, W.J. $2009 \mathrm{~b}$. Identifying the effectiveness and constraints of conservation interventions: a case study of the endangered Lesser Kestrel. Biol. Conserv. 142: 2782-2791.

DEMA 2005. Exceptional concentration of Lesser Kestrel in Estremadura threatened by changes in agriculture. Crécerellette Info, No. 3, September 2005. 
Eichhorn, G., Afanasyev, V., Drent, R.H. \& van der Jeugd, H.P. 2006. Spring stopover routines in Russian Barnacle Geese Branta leucopsis tracked by resightings and geolocation. Ardea 94: 667-678.

ESRI 1999. ArcView GIS 3.2 Computer Software. Redlands, CA: Environmental Systems Resources Institute Inc.

Ganusevich, S.A., Maechtle, T., Seegar, W.S., Yates, M.A., McGrady, M.J., Fuller, M., Schueck, L., Dayton, J. \& Henny, C.J. 2004. Autumn migration and wintering areas of Peregrine Falcons Falco peregrinus nesting on the Kola Peninsula, northern Russia. Ibis 146: 291-297.

González-Solís, J., Croxall, J.P., Oro, D. \& Ruiz, X. 2007. Trans-equatorial migration and mixing in the wintering areas of a pelagic seabird. Front. Ecol. Environ. 5: 297-301.

Greenberg, R. \& Marra, P.P. 2005. Birds of Two Worlds The Ecology and Evolution of Migration. Baltimore: The Johns Hopkins University Press.

Hill, R.D. 1994. Theory of geolocation by light levels. In Le Boeuf, B.J. \& Laws, R.M. (eds) Elephant Seals: Population Ecology, Behaviour and Physiology: 227-236. Berkeley: University of California Press.

Jones, P. 1995. Migration strategies of Palaearctic passerines in Africa. Isr. J. Zool. 41: 393-406.

Kelsey, M.G. 1992. Conservation of migrants on their wintering grounds: an overview. Ibis 134: 109-112.

LPO 2008. Dernieres nouvelles des Faucons crecerelletes au Senegal. Available at: http://crecerellette.lpo.fr/actualites.htlm [accessed 29 October 2009].

LPO 2009. Suivi et conservation du dortoir sénégalais en 2008. Crécerellette Info, No. 8/9, January 2009.

Meyburg, B.U., Gallardo, M., Meyburg, C. \& Dimitrova, E. 2004. Migrations and sojourn in Africa of Egyptian vultures (Neophron percnopterus) tracked by satellite. J. Ornithol. 145: 273-280.

Meyburg, B.U., Meyburg, C., Mizera, T., Maciorowski, G. \& Kowalski, J. 2005. Family break up, departure, and autumn migration in Europe of a family of Greater Spotted Eagles (Aquila clanga) as reported by satellite telemetry. J. Raptor Res. 39: 462-466.

Minias, P., Kaczmarek, K., Piasecka, A. \& Kuncewicz, M. 2009. Large roost of Lesser Kestrels in southeastern Albania. J. Raptor Res. 43: 166-167.

Mullié, W.C. 2009. Birds, locusts and grasshoppers. In Zwarts, L., Bijlsma, R.J., van der Kamp, J. \& Wymenga, E. (eds) Living on the Edge: Wetlands and Birds in a Changing Sahel: 202-223. Zeist: KNNV Publishing.

Negro, J.J., de la Riva, M. \& Bustamante, J. 1991. Patterns of winter distribution and abundance of Lesser Kestrels (Falco naumannı) in Spain. J. Raptor Res. 25: 30-35.

Newton, I. 2008. The Migration Ecology of Birds. London: Academic Press.

Olea, P.P. 2001. Post-fledging dispersal in the endangered Lesser Kestrel Falco naumanni. Bird Study 48: 110115.

Olea, P.P., Vera, R., de Frutos, A. \& Robles, H. 2004. Premigratory communal roosts of the Lesser Kestrel in the boreal summer. J. Raptor Res. 38: 278-282.

Pepler, D. \& Martin, R. 2001. El Cernicalo primilla en Africa: Migracion, estatus de conservacion y peligros. In Toledano, J.F.G. \& Matesanz, M.C. (eds) Biología y Conservación del Cernicalo Primilla: 318-336. Madrid: Actas del IV Congresso Nacional sobre el Cernícalo Primilla.
Phillips, R.A., Silk, J.R.D., Croxall, J.P., Afanasyev, V. \& Briggs, D.R. 2004. Accuracy of geolocation estimates for flying seabirds. Mar. Ecol. Prog. Ser. 266: 265-272.

Phillips, R.A., Silk, J.R.D., Croxall, J.P. \& Afanaysev, V. 2006. Year-round distribution of White-chinned Petrels from South Georgia: relationships with oceanography and fisheries. Biol. Conserv. 129: 336-347.

Pilard, P. 2008. Suivi et conservation du dortoir Sénégalais de deux rapaces insectivores. In LPO (eds) Résumés Des Communications du VII Congrès Internationnal sur le Faucon Crécerellette: 50. Almendralejo: Spain.

Pilard, P., Thiollay, J.M. \& Rondeau, G. 2004. Données sur l'hivernage du Faucon crécerellette Falco naumanni en Afrique de l'Ouest. Alauda 72: 323-328.

Pomarol, M. 1996. Artificial nest structure design and management implications for the Lesser Kestrel (Falco naumanni). J. Raptor Res. 30: 169-172.

Qian, F., Wu, H., Gao, L., Zhang, H., Li, F., Zhong, X., Yang, X. \& Zheng, G. 2009. Migration routes and stopover sites of Black-necked Cranes determined by satellite tracking. J. Field Orn. 80: 19-26.

R Development Core Team 2007. R: A Language and Environment for Statistical Computing. Vienna, Austria: R Foundation for Statistical Computing. http://www.R-project.org.

Rayner, M.J. 2007. Effect of dummy global location sensors on foraging behaviour of Cook's Petrel (Pterodroma cooki). Wilson J. Ornithol. 119: 109-111.

Riols, C. \& Pilard, P. 2007. Mouvements postnuptiaux 2006 du Faucon crécerellette dans le sud de la France. Crécerellette Info, No. 6/7, November 2007.

Rodríguez, A., Negro, J.J., Bustamante, J., Fox, J.W. \& Afanasyev, V. 2009. Geolocators map the wintering grounds of threatened Lesser Kestrels in Africa. Divers. Distrib. 15: 1010-1016.

Róman, J.R., Onrubia, A., Muñoz, G., Benjumea, R., Muñoz, A.R., de la Cruz, A., Gonzaléz, M., Cuenca, D., Barrios, L., Torralvo, C., Elorriaga, J., Zufiaur, P., Pérez, B., Léon, M. \& Cortés, V. 2008. The migration of Lesser Kestrel Falco naumanni across the Strait of Gibraltar. In LPO (eds) Résumés des Communications du VII Congrès Internationnal sur le Faucon Crécerellette: 67. Almendralejo: Spain.

Sánchez-Zapata, J.A., Dónazar, J.A., Delgado, A., Forero, M.G., Ceballos, O. \& Hiraldo, F. 2007. Desert locust outbreaks in the Sahel: resource competition, predation and ecological effects of pest control. J. Appl. Ecol. 44: 323-329.

Serrano, D., Tella, J.L., Forero, M.G. \& Donazar, J.A. 2001. Factors affecting breeding dispersal in the facultatively colonial lesser kestrel: individual experience vs. conspecific cues. J. Anim. Ecol. 70: 568-578.

Shaffer, S.A., Tremblay, Y., Awkerman, J.A., Henry, R.W., Teo, S.L.H., Anderson, D.J., Croll, D.A., Block, B.A. \& Costa, D.P. 2005. Comparison of light- and SST-based geolocation with satellite telemetry in free-ranging Albatrosses. Mar. Biol. 147: 833-843.

Sherry, T.W. \& Holmes, R.T. 1996. Winter habitat quality, population limitation, and conservation of NeotropicalNearctic migrant birds. Ecology 77: 36-48.

Strandberg, R., Klaassen, R.H.G., Hake, M., Olofsson, P., Thorup, K. \& Alerstam, T. 2008. Complex timing of Marsh Harrier Circus aeroginosus migration due to pre- and postmigratory movements. Ardea 96: 159-171. 
Strandberg, R., Klaassen, R.H.G., Hake, M., Olofsson, P. \& Thomas, A. 2009. Converging migration routes of Eurasian Hobbies Falco subbuteo crossing the African equatorial rain forest. Proc. R. Soc. Lond. B. 276: 727-733.

Stutchbury, B.J.M., Tarof, S.A., Done, T., Gow, E., Kramer, P.M., Tautin, J., Fox, J.W. \& Afanasyev, V. 2009. Tracking long-distance songbird migration by using geolocators. Science 323: 896.

Thiollay, J.M. 2006. The decline of raptors in West Africa: long-term assessment and the role of protected areas. Ibis 148: 240-254.

Urbanek, S. 2007. proj4: A simple interface to the PROJ.4 cartographic projections library. R package version 1.0-4. http://www.rforge.net/proj4/.

Ursúa, E. \& Tella, J.L. 2001. Unusual large communal roosts of Lesser Kestrel in two electric substations of Northern Spain: implications for the conservation of Spanish population. In Bustamante, J., Crema, G., Casado, E., Seoane, J.,
Alonso, C., Rodríguez, C., de Lucas, M. \& Janss, G. (eds) Abstracts of the $4^{\text {th }}$ Eurasian Congress on Raptors: 188. Seville: Estación Biológica de Doñana and Raptor Research Foundation.

Weimerskirch, H., Le Corre, M., Marsac, F., Barbraud, C., Tostain, O. \& Chastel, O. 2006. Postbreeding movements of Frigatebirds tracked with satellite telemetry. Condor 108: 220-225.

Wilson, R.P., Ducamp, J.J., Rees, G., Culik, B.M. \& Niekamp, K. 1992. Estimation of location: global coverage using light intensity. In Priede, I.M. \& Swift, S.M. (eds) Wildlife Telemetry: Remote Monitoring and Tracking of Animals: 131-134. Chichester: Ellis Horward.

Received 27 January 2010; revision accepted 3 October 2010. Associate Editor: Phil Battley. 